\title{
Renascimento e reforma: interfaces sociais e epistemológicas
}

\author{
Abraão Pustrelo Damião*
}

\section{Resumo}

Este trabalho constitui-se de uma análise bibliográfica acerca da história das ideias e das práticas epistemológicas que possibilitaram, em conjunto, o surgimento e a legitimação da Reforma Protestante durante o Renascimento. Para tanto, apresenta as principais características do Humanismo cultural e suas ramificações sociais, no intuito de esclarecer a sociabilidade comum que envolve o pensamento e a atividade dos indivíduos deste período. Isso significa que uma ideia pode surgir a qualquer momento, mas só ganhará força "histórica" se for ao encontro dos interesses de sua época. Neste sentido, o artigo enfatiza que a Reforma só foi possível, porque as condições materiais, intelectuais e psicológicas dos indivíduos, que participaram dela, convergiram em direção a novas ideias e práticas por ela inspiradas.

Palavras-chave: Renascimento. Reforma Protestante. Modernidade. Humanismo. História das Ideias

\section{Renaissance and reformation: social and epistemological interfaces}

\section{Abstract}

This work consists of a literature review on the history of ideas and epistemological practices that enabled together the rise and the legitimacy of the Protestant Reformation during the Renaissance. In order to do so, it presents the main characteristics of cultural Humanism and its social ramifications, in order to clarify the common sociability that involves the thinking and the activity of the individuals of this period. This means that an idea can arise at any moment, but only gain "historical" strength if it meets the interests of its time. In this sense, the article emphasizes that the Reformation was only possible because the material, intellectual and psychological conditions of the individuals who participated in it, converged towards new ideas and practices inspired by it.

Keywords: Renaissance. Protestant Reformation. Modernity. Humanism. History of Ideas

* Professor de Sociologia do Instituto Federal de São Paulo - IFSP. Doutor em Sociologia pela Unesp/Marília (com estágio sanduíche na Universidade de Lisboa - Instituto de Ciências Sociais, Portugal). Email: dirceudamiao@hotmail.com 


\section{Renacimiento y reforma: interfaces sociales y epistemológicos}

\section{Resumen}

Este trabajo se constituye de un análisis bibliográfico acerca de la historia de las ideas y de las prácticas epistemológicas que permitieron, en conjunto, el surgimiento y la legitimación de la Reforma Protestante durante el Renacimiento. Por eso presenta las principales características del Humanismo cultural y sus ramificaciones sociales, con el fin de esclarecer la sociabilidad común que envuelve el pensamiento y la actividad de los individuos de este período. Esto significa que una idea puede surgir en cualquier momento, pero sólo ganará fuerza "histórica" si está al encuentro de los intereses de su época. En este sentido, el artículo enfatiza que la Reforma sólo fue posible, porque las condiciones materiales, intelectuales y psicológicas de los individuos, que participaron de ella, convergieron hacia nuevas ideas y prácticas por ella inspiradas.

Palabras clave: Renacimiento. Reforma Protestante. Modernidad. Humanismo; Historia de las ideas.

\section{Introdução: Na aurora de um novo mundo}

O Renascimento é uma conceituação historiográfica utilizada para caracterizar as transformações sociais, culturais, econômicas e religiosas ocorridas na civilização europeia, durante os séculos XIV e XVII. Não há, porém, consenso sobre o início e término exatos do movimento renascentista. Existem diferenças consideráveis com relação às datas, aos autores e às extensões desta fase da história europeia. Contudo, sua existência, sua influência e seus reflexos foram inegáveis para a formação e consolidação da sociedade ocidental em sua tarefa de - com a decadência do sistema feudal - conceber um homem e um mundo novos.

Os humanistas - escritores, artistas, filósofos e religiosos que deram origem ao movimento cultural do Renascimento - quiseram regressar à fonte da razão e da beleza, da inventividade e do protagonismo que melhor tinham se expressado, até aquele momento, nas civilizações gregas e romanas. O Renascimento significou, portanto, e, em termos amplos, o nascimento de um homem novo que procurou a renovação moral, intelectual e política a partir de um retorno aos valores greco-romanos, e, com isso, a necessidade de diferenciar-se do período medieval, em sua busca por retornar ao período clássico e de retirar dele inspiração para suas atividades.

Neste contexto, o movimento humanista, ao contrário de seu predecessor (a escolástica), reconheceu o valor do homem em sua totalidade e buscou compreendê-lo a partir da sua história e interação social, não mais como ente transcendental. Nas palavras de Nicola Abbagnano (2012, p.602), 
os humanistas reconheceram a "historicidade do homem, dos vínculos do homem com seu passado, que, por um lado, serviram para uni-lo a esse passado e, por outro, para distingui-lo dele". Epistemologicamente, o humanismo pretendeu tratar da instrução do homem a partir das disciplinas e dos saberes formados e produzidos pelo próprio homem, por serem próprios do homem e não de outras espécies naturais ou entes transcendentais; desta forma, constituiu um discurso em que o homem é o epicentro da realidade e da produção do conhecimento.

Um ponto que não pode ser negligenciado é que o Renascimento se caracterizou mais como um processo de transição à vida moderna do que como uma cisão radical com as instituições e tradições precedentes. Não faltaram elementos de continuação entre a Idade Média e a Renascença; muitos debates e posicionamentos defendidos por humanistas e filósofos do Renascimento ainda eram os mesmos discutidos pela "idade das trevas". Isso explica a discussão entre os historiadores da cultura e da ciência, que oscilam entre dois extremos, quando debatem e interpretam este período: enquanto uns veem o Renascimento como uma ruptura, uma oposição aos preceitos e elementos medievais, outros o veem como uma continuidade dos avanços e progressos do fim da Idade Média. Assumo, frente a isso, uma postura intermediária, ou seja, analiso o Renascimento de forma dialética, ora como ruptura, ora como continuidade do período precedente. Isso porque a renovação religiosa, expressa pela Reforma, ora se apresentou como um retorno às origens da revelação original, ora como forma de restabelecer o contato com o cristianismo da antiguidade, ignorado pela tradição medialesca.

Assim, busco, principalmente, entender as condições sociais e epistemológicas que possibilitaram a virada religiosa e cultural do ocidente a partir da ação e das ideais propostas pelos "reformadores da fé". Argumento, com isso, que a renovação da fé só pode ser totalmente compreendida se levadas em conta suas raízes renascentistas.

\section{As condições sociais para a renovação da fé}

$\mathrm{Na}$ contramão das utopias propositivas, o imaginário de um grande e maravilhoso mundo cristão começou a desabar antes mesmo da Reforma de Lutero, em 1517. Isso porque, a partir do século XV, os grandes impérios europeus cederam espaço à formação de estados nacionais mais regulados e funcionais; as revoluções marítimas alargaram o mundo "conhecido"; a 
natureza começou a ser objeto de estudo graças a uma nova visão de mundo e importantes desenvolvimentos técnicos e científicos. Tudo isso permitiu ao Renascimento produzir as bases econômicas, sociais, culturais e educacionais da Reforma, num ambiente em que os grilhões da idade média se esgotavam.

Hannah Arendt (2010) apontou três eventos da renascença que mudaram a cara da modernidade: o uso do telescópio por Galileu, a Reforma Protestante e a Expansão marítima. Culturalmente, esses três eventos trouxeram progressos fundamentais à humanidade, obrigando o homem ocidental a uma ânsia realística. O telescópio reafirmou o heliocentrismo, proposto por Copérnico, e o antropocentrismo, ao passo que deslocou Deus do centro do universo; a Reforma escrachou a passividade do catolicismo em favor da livre iniciativa e da liberdade interpretativa da palavra de Deus; enquanto a Expansão Marítima pôs fim à noção de paraíso cristão, que cedeu lugar ao realismo do novo mundo. Ainda segundo H. Arendt, a consequência mais importante destas transformações foi o reviver do individualismo, que produziu originalidade na percepção de si e dos outros, e alavancou o espírito crítico e o relativismo existencial: fez o indivíduo experimentar a solidão e dar-se conta de sua própria pequenez, tornando o antro, ou a representação dele, uma propedêutica indispensável à civilização ocidental.

Contudo, o avanço das liberdades individuais em contrapartida ao enfraquecimento das tradições e hierarquias do passado não ocorreu sem aflições. A renascença trouxe consigo uma profunda melancolia, não no sentido psicanalítico, mas a melancolia de um indivíduo que emergiu do anonimato medieval para virar protagonista de sua própria vida, ao mesmo tempo em que se deu conta de sua própria fragilidade. A melancolia é evidenciada pela presença de dois elementos constantes nas obras artísticas e literárias do período: a morte e as discussões morais. "A vida que não vale a pena ser vivida apareceu frequentemente na obra dos escritores" (Delumeau, 1984, p.48), ao mesmo tempo em que "a promoção do indivíduo e o sentimento de culpabilidade pessoal foram duas realidades inseparáveis” (Ibidem, p.51).

Esperança, deslumbramento e entusiasmo; morte, melancolia e dilemas morais: discussões frequentes da renascença, como notamos nas obras de Erasmo de Roterdã (1466-1536), Elogia da Loucura (1509) e Da Civilidade da Criança (1530), que trazem críticas à rigidez da tradição cristã-medieval (que impedia o autodesenvolvimento dos indivíduos e os envolvia em uma carapaça de dúvidas e angústias), bem como dos costumes da época, de Thomas More (1478-1535), que materializou em A Utopia (1516) os desejos 
e fantasias de um povo que vislumbrava a paz e a igualdade, pois sofria diuturnamente com as injustiças do cotidiano, de Miguel de Cervantes, que em Dom Quixote (1605) juntou todas estas discussões e sentimentos em um só homem que transcendia o mundo, não mais graças a divindades, mas sim a partir de seus sonhos e desejos, de William Shakespeare (1564-1616) que mostrou a capacidade orquestrada da vingança e da tradição em Hamlet (1601) e do amor incondicional e impossível em Romen e Julieta (1595) ou ainda de Dante Alighieri (1265-1321), que na forma de poema/narrativa, não só contou uma bela história sobre os ideais religiosos e morais de uma época, como também ajudou a lançar as bases da língua italiana moderna a partir de A Divina Comédia (1304-1321).

Com pensamentos mais pragmáticos, porém não menos importantes, Nicolau Maquiavél (1469-1527), em O Príncipe (1513), pôs em xeque a moral cristã e exaltou a virtude (força) que um príncipe precisava para unir e governar uma nação; na França, Jean Bodin (1530-1596), em Os seis Livros da República (1576), sistematizou os ideais da nova política absolutista e da nova mentalidade burguesa, ao decretar a inviolabilidade da propriedade privada; enquanto, na Inglaterra, Thomas Hobbes (1588-1679), em O Leviatã (1651), apresentou as diretrizes da ciência política moderna e sem titubeios mostrou quão bárbaro e animalesco seria o homem em estado de natureza. A originalidade desses autores, segundo Max Weber (2006, p.24), foi terem sistematizado um método de análise factual e conceitual racionalmente estruturado para as ciências políticas e a teologia moderna.

Para além do aspecto literário, as discussões e inovações culturais ressoaram na arte renascentista. Michelangelo (1475-1564), Rafael Sanzio (1483-1520), Donatello (1386-1466), Giorgio Vasari (1511-1574), Masaccio (1401-1428), entre outros, buscaram incessantemente realizar representações fidedignas da realidade, da natureza e dos homens. O resgate das referências antigas fez com que eles refutassem o idealismo artístico e se voltassem ao cotidiano, retratando, assim, o mundo dos homens, com suas misérias, deformidades, alegrias e conquistas. Este viés estético, epistemologicamente influenciado pelo naturalismo, ajudou a criar uma mentalidade importante na renascença: a de que era possível captar a essência da realidade (Delumeau, 1984).

Segundo Phelipe Ariès (1979), a nova postura literária, política e estética, fez o Renascimento, além de afirmar a individualidade da natureza como valor fundamental, "descobrir" a infância, a mulher e a família. 
Desde a Antiguidade até a idade média, as crianças eram desprezadas e não recebiam nenhum tratamento especial; a duração da infância era reduzida e as crianças, ao apresentarem independência física, eram colocadas no "mundo" adulto. A educação infantil não era administrada pela família, mas sim por meio da convivência, a partir das tarefas, com os adultos. Isso, durante o Renascimento, mudou. A infância deixou de ser "abstrata", as crianças deixaram de ser adultas em miniatura e passaram a ser vistas como algo novo, que por suas práticas, hábitos e necessidades, precisavam de uma forma diferente de atenção e investimento social, sobretudo porque a melhor condição material da aristocracia burguesa e da vida urbana, permitiu que um número cada vez menor de crianças precisasse trabalhar ou se dedicar a trabalhos árduos como os do campo, possibilitando, assim, que os "novos ricos" dessem mais atenção a seus filhos e os vissem como algo a se investir. Ao mesmo tempo, a melhoria das condições econômicas requereu um apoio cada vez maior das esposas e empregadas para o sustento dos negócios. Em linhas gerais, o direcionamento das funções familiares para os negócios, o anonimato urbano, o questionamento (mesmo que brando) da estrutura familiar cristã pela reforma - que aboliu os votos religiosos e consagrou o sacerdócio universal - e uma perspectiva mais autônoma dos sujeitos, libertou a família de um sistema rígido de comportamento e permitiu-lhes uma vida privada mais íntima.

O Renascimento também deu grande zelo à escola: a educação moral e pedagógica das crianças e a instrução como forma de ascensão social tornaram-se comuns neste período. Numa civilização mais laica e menos militar (mais pacífica), a instrução formal e cultural alcançou relevância permanente, tornando-se uma das formas de distinção social. Não houve, contudo, uma ruptura abrupta entre o ensino medieval e o da renascença, o que existiu de fato é que, durante o Renascimento, a instrução alcançou outros patamares e alargou-se. Tanto protestantes quanto jesuítas ainda queriam formar "homens cristãos". Os colégios mantiveram a espinha dorsal da pedagogia medieval que se baseava no ensino do Trivium (gramática, retórica e dialética) e do Quadrivium (geometria, aritmética, astronomia e música). Interessante notar que esta base pedagógica durou até o século XIX no continente europeu, com uma exceção, fundamental em termos históricos e epistemológicos: a dialética grega desapareceu, dando lugar à lógica, que passou a ser equivalente à filosofia, exceto na Inglaterra. Neste contexto, o saber mais importante, depois do religioso, era o da história, 
disciplina introdutória fundamental para conhecer os homens e os dignos exemplos a serem seguidos e imitados. Apesar de a educação formal manter os preceitos da escolástica, a reorganização das estruturas educacionais e as novas perspectivas morais e culturais trazidas pelo Renascimento foram fundamentais para minar, pouco a pouco, as prerrogativas medievais da educação familiar e informal (Almeida, 2005).

Enquanto as estruturas de ensino se transformavam e ganhavam relevância, a vida cultural e psicológica dos pupilos também se alterava. Crianças e jovens já eram vistos como diferentes dos adultos nos bancos escolares e era preciso protegê-los, tutelá-los. Os jesuítas, neste quesito, foram os que melhor captaram esta tendência, ao introduzir, na educação, uma forte disciplina para afastar as crianças da corrupção e pecado adultos. Os tutores deveriam ser responsáveis pela conduta moral de seus alunos. Por outro lado, os protestantes instruíram seus alunos para a ascese e a formação técnica. A racionalidade instrumental-produtiva irrompeu na educação dos reformadores. Apesar destas diferenças, a disciplina tornouse ponto comum entre católicos e protestantes e "a disciplina dos colégios permitiu à civilização ocidental polir-se, afinar-se, moralizar-se” (Delumeau, 1984, p.79), engendrando um novo padrão comportamental em que noções de boas maneiras, etiqueta e obediência eram cada vez mais importantes, como lembra Nobert Elias (1994).

Podemos dizer que, mais culta e rica material e espiritualmente, a sociedade renascentista foi tomada por um tipo específico de prática epistemológica advinda da história e filosofia natural. Segundo John Henry (1998, p.42):

A motivação social que ocasionou essa mudança no trabalho em história natural foi essencialmente dupla. Em primeiro lugar ela pode ser vista como uma extensão das preocupações humanistas do Renascimento com a superioridade moral da vita activa em relação à vida contemplativa, abarcando tanto disciplinas úteis para o Estado, como a ética, o direito, a política, a retórica, quanto um conhecimento útil, pragmático, da natureza. Mostrava-se nestas obras que o conhecimento da história natural era útil no comércio, na agricultura, na culinária, na medicina e em várias outras áreas que serviam ao bem público tanto quanto a filosofia moral do humanismo cívico [...]. Em segundo lugar, a história natural era vista como um meio de exibir as maravilhosas, sabedoria, arte e benevolência do Criador. Desse ponto de vista, a história natural podia ir muito além das preocupações antropocêntricas da vita activa e considerar criaturas que pareciam não ter nenhum valor medicinal, 
culinário ou comercial. O resultado dessa ênfase religiosa foi que botânicos e zoólogos puderam reivindicar um crédito intelectual maior que aquele geralmente conferido à disciplina meramente descritiva da história natural. O historiador natural lia o segundo livro de Deus, o livro da Criação, para suplementar a leitura das Escrituras pelos teólogos.

Como bem resumiu Battista Mondin (1986, p.12), "ao ideal cristão de desapego do mundo, de mortificação do corpo, de domínio das paixões, os humanistas contrapunham o ideal clássico da realização de todas as paixões, da beleza do corpo, do vigor físico, do gozo alegre dos bens deste mundo", pois o Deus transcendente havia sido substituído pelo Deus imanente. Isso porque os intelectuais naturalistas foram essencialmente deístas, acreditaram na imanência da natureza (que possui em si seu próprio princípio e seu fim) e desprezaram a visão transcendente do monoteísmo; para eles, revelar a natureza era revelar o próprio Deus, que se manifestava através da razão. Perder isso de vista é deixar escapar (talvez) a maior motivação do naturalismo enquanto prática epistemológica (Damião, 2018).

Em termos ontológicos, todas essas condições sociais promovidas pelo Renascimento emergiram a noção de indivíduo autônomo a um patamar original. Os homens começaram a se ver como sujeitos, muito mais do que um coletivo coeso, uma corporação, um partido ou outra feição de coletividade. Claro que a sociedade (conservadora) ainda exercia um forte poder sobre o controle das pulsões individuais, mas a renascença abalou as tradições seculares de uma forma imprescindível para o desenvolvimento de novos habitus que valorizavam a autonomia e o individualismo.

Não é por acaso, portanto, que o espírito crítico do Renascimento encontrou as bases para o seu protesto, em parte, no próprio evangelho, ao acusar (às vezes satiricamente) as restrições da Igreja e os abusos dos chefes eclesiásticos ou pagãos que se intitulavam cristãos, mas utilizavam-se muito mal dos preceitos de Jesus. Neste sentido, segundo Jean Delumeau (1994, p.146),

O humanismo cristão foi unânime no duplo desejo de purificar a Escritura das traduções defeituosas e de dar aos fiéis o verdadeiro texto da bíblia [...]. Os humanistas iam, neste ponto, ao encontro das aspirações profundas do seu tempo. Uma devoção mais individualista que a do passado só podia desejar este contato mais pessoal com a mensagem divina. 
Nobert Elias (1994, p.172) reitera as observações de Delumeau ao sustentar que "os humanistas eram representantes de um movimento que buscava libertar a língua latina de seu confinamento a esfera e tradição eclesiásticas e torná-la a língua da sociedade secular, pelo menos da classe secular".

Outro elemento importante de desestabilização ideológica (ou das ideias), durante a renascença, decorreu da ruptura (ou questionamento) dos princípios anteriores de autoridade. A maioria das influências nas quais se ancorava a perspectiva medieval do mundo e toda a cristandade estava em crise: a hegemonia de Aristóteles na filosofia, a de Agostinho e Aquino na teologia, a de Ptolomeu na astronomia, a do Papa e dos Reis na política, a dos senhores na economia, a da religião na cultura.

Portanto, uma reforma era mais que necessária para engendrar uma nova ordem espiritual e civil que não mais fossem baseadas em autoridades tradicionais. A Igreja de cristo precisava, assim como outros aspectos da realidade, recuperar (ou melhor, acender) a luz da renovação outrora ofuscada pelas transformações do Renascimento.

\section{O nascimento de um pensamento religioso disruptivo e suas premissas fundamentais}

Essa nova luz veio - sem que seu postulante tivesse clara intenção de se revoltar contra Roma - em 31 de outubro de 1517, quando o frade alemão Martin Lutero (1483-1546) afixou suas 95 teses na porta de uma Igreja de Wittenberg ${ }^{1}$. Lutero, estabelecendo-se intérprete de um sentimento humanista profundamente difundido em seu tempo, conseguiu realizar uma reforma significativa da Igreja e da fé.

Grandes acontecimentos, como a Reforma, não podem ser creditados ao trabalho de um único homem. Ninguém, por si só, é um profeta das verdades universais. A exceção à regra são algumas descobertas científicas, como o heliocentrismo, a lei da gravitação universal etc., mas mesmo estas estão sujeitas ao acúmulo de conhecimento e ao desenvolvimento de instrumentos técnicos que ultrapassam a capacidade individual do cientista. Lutero, contudo, transformou-se no símbolo da Reforma por sua

Este era um método comum à época para instigar o debate aberto sobre algum tema. O fato é que a ousadia de Lutero foi tão significativa que alguns historiadores apontam o início da modernidade não na descoberta da América (1492), mas na atitude de Lutero em Wittenberg. 
capacidade argumentativa e pelo alcance de suas ideias que, definitivamente, transformaram a cultura moderna.

O mote inicial da preocupação teológica de Lutero foi a questão da salvação. Seu objetivo principal era dar uma resposta aqueles que queriam saber (como ele) como salvar a alma, já que apesar de todos os juramentos, penitenciais, sacrifícios, angústias e boas ações, a salvação lhe soava inalcançável. Sua resposta veio do resgate, de São Paulo, da doutrina da "Justificação pela Fé", sola fide, em que o apóstolo afirma: "o justo viverá pela fé" (romanos 1:17). A partir de uma interpretação literal da doutrina, Lutero pôde, através de argumentos até mesmo poéticos, desvencilhar a necessidade de uma intermediação da Igreja para a salvação do fiel, bem como de que o fiel deveria pagar por sua salvação ou realizar boas obras para a Igreja como recompensa à salvação. Desta forma, Lutero, defendeu incisivamente que a salvação só poderia ser encontrada em Deus, que prometeu a salvação por intermédio de seu filho, não de uma instituição. No centro da revolta de Lutero estava sua convicção de que, predisposto ao pecado, somente Deus poderia salvar o homem, e não aqueles que supostamente falavam ou agiam em nome dele. Ou seja, a absolvição divina é um dom a ser aceito e não uma recompensa a ser conquistada.

Para justificar sua teologia - e avançar na interpretação e alcance das 95 Teses - Lutero publicou, em 1520, as três obras fundamentais da Reforma: À nobreza cristã da nação alemã, Do cativeiro babilônico da Igreja e Da liberdade do cristão, que, em conjunto, formam o núcleo "duro" da teologia luterana.

Em À nobreza cristã da nação alemã, aceca do melhoramento do estamento cristão, 1520, Lutero dedicou-se a desmontar as três premissas básicas sobre as quais a Igreja de Roma havia exercido seu poder sobre a cristandade até então: o controle do poder secular, a exclusividade da interpretação da palavra e o direito único para convocação de concílios ecumênicos. Em suas palavras:

Com muita astucia os romanistas se circundaram de três muralhas, com que até agora se protegeram, de sorte que ninguém os pôde reformar, razão por que toda cristandade decaiu terrivelmente. Em primeiro lugar: quando se os apertou com o poder secular, determinaram e disseminaram que o poder secular não tem direito sobre eles, e sim o contrário: o eclesiástico estaria acima do secular. Segundo: quando os quis censurar com base na Sagrada Escritura, eles objetavam dizendo que a ninguém cabe interpretar a Escritura senão ao Papa. Terceiro: quando ameaçados com um concílio, inventam que 
ninguém pode convocar um concilio senão o Papa. Assim, nos roubaram às ocultas as três varas, para poderem ficar impunes, e tomaram lugar na segura fortaleza destas três muralhas, para praticar toda sorte de vilanias e maldades que agora vemos. [...] Intimaram com isso a reis e príncipes, a ponto de estes acreditarem que seria contra Deus se não lhes obedecessem em todas essas fantasmagorias maliciosas e astutas (Lutero, 1987, p.281).

Segundo o monge agostiniano, todas as três muralhas não se sustentavam frente a constatações óbvias. "Inventou-se que o papa, os bispos, os sacerdotes e os monges sejam chamados de estamento espiritual; príncipes, senhores, artesão e agricultores de estamento secular" (Ibidem. p.282). Nada mais falso do que isso, pois desde que se tenha o mesmo Batismo, a mesma Escritura e a mesma fé, são cristãos igualmente. Portanto, separar o poder secular do religioso é um contrassenso injustificável. Lutero, aceitando os pressupostos humanistas de seu tempo, convidou os seculares a tornarem-se membros do corpo cristão: "o poder secular cristão deve exercer seu ofício livre e desimpedidamente, sem consideração de quem está atingindo, seja papa, bispo ou sacerdote" (Ibidem, p.284).

Seguindo a orientação de H. Arendt (2007, p.265) e para que não haja confusão terminológica ou generalizações abstratas, temos que ter em mente que:

Como evento histórico tangível, a secularização significa apenas a separação entre Igreja e Estado, entre religião e política; e isto, do ponto de vista religioso, implica um retorno à antiga atitude cristã de dar "a Cesar o que é de Cesar e a Deus o que é de Deus", e não uma perda da fé e da transcendência ou um novo e enfático interesse nas coisas deste mundo.

Segundo Martin Seymour-Smith (2002, p. 246), o próprio Lutero

Chamava a razão de "Puta do Diabo", na verdade uma expressão tola, mesmo que saibamos o que ele queria dizer, ou seja, que a faculdade de raciocinar fora corrompida pelo pecado original e consequentemente não era adequada para julgar a maneira como os homens deveriam pensar sobre Deus.

Portanto, quando Lutero ou Calvino se referem ao universo secularizado não o fazem no mesmo sentido que os Iluministas ou que os marxistas e niilistas do século XIX. 
Retomando. A segunda muralha, não obstante, é débil e dispersa. Os mestres da Igreja "querem ser mestres exclusivos da Escritura, ainda que, durante toda vida, nada aprendam nela. Atrevem-se a atribuir exclusivamente a si próprios a autoridade" (Lutero, 1987, p.286) quando, na verdade, não encontram uma justificativa na Escritura para esta autoridade exclusiva do uso da palavra de Deus. Ao contrário do que pregam, São Paulo (em 1 Co. 14.30) ensinou que: "se a alguém se revela algo melhor, mesmo que esteja sentado e ouvindo o outro na palavra de Deus, o primeiro que está falando deve calar-se e ceder". Portanto, “[...] somos todos sacerdotes [...] todos temos uma fé, um Evangelho, o mesmo sacramento. Como não haveríamos também de ter o poder de perceber e julgar o que seria correto ou incorreto na fé?" (Ibidem, p.285). As palavras de Lutero foram duras para aqueles que viam-se imunes a críticas, especialmente porque a soberania da verdade e do discurso religiosos começavam a ser questionadas como nunca antes, desde as camadas mais baixas até as mais "intelectualizadas.

"A terceira muralha cai por si mesma, ao caírem as duas primeiras" (Ibidem, p.286), ou seja, se o papa não segue a Escritura e não possuí a autoridade por ele reivindicada, não cabe a ele a exclusividade na convocação ou confirmação de concílios.

Derrubadas as muralhas, Lutero volta sua atenção para o objetivo da obra: fazer um apelo aos príncipes alemães para que tomassem frente na reforma da Igreja e da fé e que juntos tragam para si o poder das dioceses, e convençam o clero e os fiéis a formarem uma verdadeira Igreja Nacional, independente e livre dos dogmas romanos, que seja contra os impostos abusivos de Roma e decrete o fim do celibato, das festas, das indulgências e das peregrinações (excetuando-se aos domingos).

Neste contexto, não podemos compreender a vanguarda germânica sobre a reforma religiosa se não levarmos em conta a questão do "nacionalismo" - a busca genuína dos alemães para reforçar seus principados em detrimento da influência latina ou saxônica - e, consequentemente, a necessidade de se formar uma intelligentsia capaz de enfrentar o julgo das influências estrangeiras; Lutero, como poucos, soube captar este espírito da época.

Sobre isso Battista Mondin (1986, p.28) afirma que:

A Reforma era necessária para todas as nações cristãs: para a Itália como para a França, para a Áustria como para a Suíça, para a Alemanha como para a Polônia, para os Países Baixos como para Inglaterra. E, no entanto, 
ela começou na Alemanha [...], porque para eles a reforma se impunha com urgência tanto por motivos religiosos e ideológicos quanto sociais e políticos: havia um anseio geral de libertar-se do jugo do papado e do império, por subtrair-se ao predomínio dos povos latinos e livrar-se dos "gravames" da cúria romana.

Com À nobreza cristã da nação alemã, acerca do melhoramento do estamento cristão, Lutero trouxe a reforma política para dentro (como parte) da reforma religiosa, apontando a necessidade de uma nova institucionalização da fé, através de outros referenciais que não mais os católicos. Isso permitiu que a reforma da fé encontrasse substrato político suficiente para ser posta em prática e defendida, por meio de instituições novas ou por meio de prerrogativas legais, sem as quais as ideias luteranas logo seriam censuradas ou eliminadas, assim como seu autor.

Assentadas as bases "sociopolíticas" da Reforma, coube a Lutero lançar os fundamentos teológicos fundamentais do protestantismo. Esses fundamentos começaram a ser - de forma inicial - apresentados em seu outro trabalho de 1520, Da Liberdade do Cristão, em que expôs sua teoria da justificação.

Lutero parte de uma tese paradoxal para começar seus argumentos: "1) O cristão é um senhor libérrimo sobre tudo, a ninguém sujeito". 2) "O cristão é um servo oficiosíssimo de tudo, a todos sujeito". Esta dubiedade é remetida a duas falas de São Paulo: "Embora sendo livre, fiz-me escravo de todos" (1 Co 9.19) e "A ninguém fiqueis devendo qualquer coisa, exceto que vos ameis uns aos outros" (Rm 13.8). Para tentar esclarecer este paradoxo Lutero (1987, p.437) diz: "ora, por sua natureza o amor é oficioso e submisso ao que é amado. Assim, também Cristo: embora senhor de todos, foi feito de mulher, feito sob a lei, simultaneamente livre e servo, ao mesmo tempo na forma de Deus e na forma de servo".

Estas contradições são parte constituinte da própria condição humana, composta de uma natureza espiritual (interna) e uma natureza corporal (externa). Enquanto a primeira preza pelo bom e pelo justo, a segunda desliza em tentações e necessidades mundanas. Por isso, na própria Escritura, existem passagens contraditórias sobre a mesma pessoa, cabendo ao bom observador identificar a natureza presente nos momentos narrados. Esta constatação é fundamental à doutrina luterana, pois é na natureza interna do indivíduo que está a sua salvação, ele não precisa da observância da lei, de boas obras, de 
penitências, enfim, de nada que seja externo para sua salvação, apenas da misericórdia e da confiança de Deus.

Nas palavras de Lutero (op. cit. p.438):

Uma só coisa é preciso para a vida, a justiça e a liberdade cristã, e somente esta: é o sacrossanto Verbo de Deus, o Evangelho de Cristo [...] Portanto, temos que ter por certo e estabelecido firmemente que a alma pode carecer de todas as coisas exceto da palavra de Deus, sem a qual absolutamente nenhuma coisa lhe é de valia" Tendo, porém, a Palavra, ela é rica, de nada mais carecendo, visto ser a palavra da vida, verdade, luz, paz, justiça, salvação, alegria, liberdade, sabedoria, virtude, graça, glória e de todo bem em medida inestimável.

Essas ideias iniciadas em Da liberdade do cristão foram completadas em Do cativeiro babilônico da igreja. O Cativeiro é considerada a obra teológica mais importante de Lutero, seu título refere-se ao cativeiro imposto por Nabucodonosor, rei da Babilônia, a Jerusalém. Esta analogia foi utilizada para mostrar que o povo de Deus estava sendo mantido cativo como outrora fora o povo de Israel. Seu objetivo, por razões fideístas, era mostrar "a incapacidade do homem e a onipotência de Deus, em virtude das quais o homem e Deus estão separados por um abismo tão grande que nenhuma série de intermediários jamais poderá transpor" (Mondin, 1986, p.36).

Para tanto, diz Lutero (op. cit. p.349):

[...] devo negar os sete sacramentos e admitir, por agora, somente três o Batismo a Penitência e o Pão. Todos esses nos foram reduzidos a um mísero cativeiro pela cúria romana. E a Igreja foi privada de toda sua liberdade. Não obstante, se quero falar de acordo com o costume da Escritura, não tenho mais que um sacramento e três sinais sacramentais.

Os sete sacramentos negados por Lutero são: Batismo, confirmação, eucaristia, penitência, extrema-unção, ordens sagradas e casamento. Como ele mesmo afirma, é preferível reduzir estes sete sacramentos a apenas um: a palavra de Deus, que está representada por três signos sacramentais: Batismo, penitência e pão (eucaristia). É preciso enxergar que esta postura de Lutero dentro de uma lógica eclesiológica ampla, vai ao encontro de sua nova concepção de justificação. Se a salvação deve ser um atributo exclusivamente individual, baseada unicamente nas palavras e misericórdia de Deus, não há razão de existir as estruturas da Igreja Romana destinadas à intermediação indivíduo/Deus. Portanto, os próprios sacramentos não 
fazem sentido de existir. O Batismo, o pão e a penitência, contudo, podem e devem ser conservados, não como pregavam os iluminados de Roma, mas como instrumentos para significar a salvação. Pois, "o que é mais importante, tanto no Batismo como na ceia, não são as cerimônias, mas as palavras com as quais se anunciam as palavras de Deus" (Mondin, 1986, p.33). "Por isso deve-se dar a todos os leigos todo o Sacramento do Pão, assim como se dá todo o Batismo e toda a Absolvição, caso o pedirem” (Lutero, 1987, p.351).

Sobre o Batismo, Lutero agradece a misericórdia de Deus por deixar este sacramento incontaminável. "Bendito o Deus [...] que conservou pelo menos este único sacramento em sua Igreja ilibado e incontaminado pelas prescrições dos seres humanos. Fê-lo livre para todos os povos e todas as classes de pessoas" (Ibidem, p.375). Esta postura é fundamental já que é do Batismo que decorre a premissa básica de toda salvação, pois é a promessa divina que afirma: "Quem crer e for batizado será salvo" (Mc 16.16). Ou seja, do Batismo nasce toda a fé que nos guia à salvação. Entretanto, Lutero nos alerta, por si só, batizar-se não significa salvar-se, é preciso estar constantemente vigilante na fé e nos preceitos de Deus. A salvação é uma obra de vida, é a recompensa de uma comunhão com Deus, e seus persignos, durante toda vida.

Também na eucaristia o que é mais importante é a mensagem de Deus, pois “a missa ou o Sacramento do Altar é o testamento de Cristo que, ao morrer, nos deixou para ser distribuído a seus fiéis” (Ibidem, p.362). É preciso, portanto, que os homens deixem de lado todas as preocupações exteriores (sejam materiais, sejam espirituais) e regressem à devoção primitiva e simples do sacramento, se quiserem comungar genuinamente com Deus já que "a missa [...] é a promessa do perdão dos pecados que Deus nos fez, e é promessa tal que foi confirmada pela morte do Filho de Deus [...] \{e se é promessa\} não chegamos a ela por nenhuma obra, nenhum esforço, nenhum mérito, mas somente pela fé (Ibidem).

Não podemos esquecer que, paralelamente à sua produção intelectual/ teológica, a atitude de Lutero de traduzir o livro sagrado foi imprescindível, num triplo sentido, para as transformações da vida social no ocidente. Em primeiro lugar, porque "na época da Reforma o veículo de descida à vida popular era a religião: as Igrejas protestantes é que garantiram a transição da cultura pós-medieval para um mundo mais democrático e secular" (Anderson, 1998, p.150). Em segundo, porque reforçou a vanguarda nacionalista germânica em sua tarefa de se afastar de Roma. Em terceiro, porque sua 
tradução do livro sagrado para o alemão, estimulou a livre interpretação das escrituras e deu impulso às traduções, não só de textos sagrados, mas também de obras profanas, permitindo, nas palavras de John Thompson (1998, p.62), a expansão "de novos sistemas de comunicação que possibilitaram a partilha de símbolos e crenças expressas numa língua comum [...] ainda que estes indivíduos nunca tivessem interagido diretamente”.

Esse conjunto de ideias de Lutero ganhou ainda mais força na Alemanha através de seu compatriota e amigo Philipp Melanchton (14971560), que estabeleceu a ortodoxia luterana dentro das Igrejas reformadas. Sua teologia, como a de Lutero, "teve como princípio material a justificação sem obras e como princípio formal a sola scriptura" (Mondin, 1986, p.40); a sola scriptura consolidou a crítica severa à interpretação alegórica da bíblia - muito comum entre padres e escolásticos - enquanto a justificação sem obras pôs em prática a noção teológica de justificação pela fé de Lutero. Melanchton, segundo Mondin (1986), só não foi considerado o herdeiro natural de Lutero por ser um sujeito moderado e pouco propenso a embates teóricos, o que tornou sua importante atuação "menor" dentro da historiografia da Reforma.

A questão é que, para incredulidade da Igreja de Roma, o movimento luterano rapidamente se espalhou pelos Países Baixos, Prússia e Suíça. O grande responsável por levar as ideias de Lutero à Suíça não foi Calvino (1509-1564), mas o pastor Ulrich Zuínglio (1484-1531). Seguidor de Erasmo - considerado por ele o primeiro a pregar a Reforma - Zuínglio, logo após sua ordenação, em 1506, começou a criticar as indulgências e a comentar as Escrituras de forma direta, seguindo a orientação (sola scriptura) de Melanchton. Entre os anos de 1522-24, condenou o celibato e o jejum (apesar de ainda os aceitar parcialmente) e revoltou-se contra o culto a imagens e santos, ao dogmatismo, ao poder papal e às missas em latim. No entanto, devido a sua postura teórica realista, Zuínglio divergiu, em muitos pontos, de Lutero; por exemplo, reduziu o "pecado original a um simples vício hereditário não merecedor de condenação eterna e sem diminuição das forças éticas do homem" (Mondin, 1986, p.37); vislumbrou o "valor positivo da Lei e não meramente negativo" (Ibidem); e estendeu o reino dos céus "aos sábios pagãos que tivessem praticado a lei moral natural" (Ibidem).

Quem, contudo, transformou Genebra na "Roma do protestantismo" e deu nova vida à Reforma foi o francês João Calvino. Calvino já havia escrito sua obra Institutas da Religião Cristã (1536) e angariado vários discípulos de Zuínglio quando foi para Genebra, que com o apoio da alta aristocracia, 
transformou no experimento de sua doutrina. Na capital Suíça, implantou uma disciplina férrea, voltada ao trabalho e ao sacrifício, proibiu os jogos de azar e condenou vários católicos e intelectuais à morte até que sua Igreja funcionasse de acordo com sua vontade.

Seu centro teológico é a doutrina da predestinação, segundo a qual, independentemente da fé e das boas obras, o homem está fadado ao inferno ou ao céu pela vontade de Deus que - distintamente do que imaginava Lutero - não é misericordioso nem voluntarioso, sequer na compreensão de seus desígnios. Segundo Calvino (2003, p.283).

Jamais haveremos de ser claramente persuadidos, como convém, de que nossa salvação flui da fonte da graciosa misericórdia de Deus, até que sua eterna eleição se nos faça conhecida, a qual, mercê deste contraste, ilumina a graça de Deus, a saber, que ele não adota à esperança da salvação a todos indiscriminadamente; ao contrário, ele dá a uns o que nega a outros

A doutrina da predestinação - exposta de maneira crua e direta, por vezes até radical, por Calvino - levou ao extremo a noção de Lutero da salvação como obra exclusiva de Deus, sem intermediários. Essa postura calvinista, sugere Zygmunt Bauman (2000, p.160), foi a grande responsável por "privatizar o negócio da salvação", ao fazer de cada indivíduo "um sacerdote". Ainda segundo Z. Bauman, a "salvação foi o primeiro bem público a ser privatizado nos tempos modernos, enquanto o arrependimento e a redenção foram as primeiras atividades ritualizadas, sincronizadas e coordenadas a serem desregulamentadas" (Ibidem). Podemos concluir que "a estrela guia da Reforma foi a liberdade individual de tomar e trilhar o caminho que leva à salvação eterna através da sua própria obra em vida" (Ibidem). A partir de então, a modernidade abriu as portas para todas as diferentes formas de privatização e desregulamentação da vida pública.

No mesmo tom, o calvinismo colocou abaixo a doutrina da justificação pela fé. Segundo Calvino (2003, p.247) "ainda que viesse a acontecer que possuíssemos algumas obras absolutamente puras e perfeitas, no entanto, um só pecado é suficiente para ofuscar e extinguir toda lembrança de justiça anterior". Assim, "as boas obras não são meios de redenção de pecados, mas frutos de justiça do coração regenerado" (Ibidem). Calvino queria deixar claro que, apesar das boas ações, o pecado ronda a vida humana e a salvação não pode depender de nenhuma outra coisa senão da vontade de Deus; o máximo que as boas ações podiam expressar, neste sentido, é a predestinação, pois 
aqueles que as praticam - geralmente - possuem as almas regeneradas. Disso decorre o moralismo e o puritanismo típicos do calvinismo, que, como muito bem observou Max Weber (2006), revertem-se objetivamente no trabalho. M. Weber acentua que a verdadeira ética protestante (no tocante ao capitalismo) é a ética calvinista, e não a de caráter luterano (apesar de muitos - desavisados - interpretarem-na como se fosse a mesma coisa).

Este é um ponto crucial para se entender a influência da Reforma sobre o desenvolvimento econômico da modernidade, pois "não fora uma simples perda de fé a causa da inversão de valores entre trabalho e labor, mas sim a perda da certitudo salutis, a certeza da salvação" (Arendt, 2007, p.290). Essa perda trouxe uma tripla determinação que não podemos perder de vista: em primeiro lugar, definiu uma espiritualidade mais personalista que consagrou o individualismo religioso; em segundo - e como consequência - assentou o sentimento de culpabilidade pessoal como característica inerente da civilização ocidental; enquanto, ao propor a renovação da cristandade sobre a lógica do trabalho e do sacrifício, converteu à concepção de fazer (razão instrumental) da sociedade burguesa a meta-propósito do conhecimento a ser atingido.

O mais importante aqui é que essa nova condição espiritual foi ao encontro da postura protestante mais ativa de expurgo dos pecados, por meio de ações e trabalhos individuais. o trabalho previamente visto como inferior e pertencente a classes subalternas ou como uma penitência imposta aos homens pelo pecado original (implicando dor e sofrimento), passou a ser condição essencial para a redenção cristã que, se alcançada e merecida, geraria riqueza e dignificaria o homem. Com isso, cabia aos protestantes, moral e fisicamente, redimirem-se da culpa, abdicar dos prazeres e voltaremse ao labor produtivo, por meio de uma ascese que levasse à realização dos desígnios divinos e das leis sagradas. Por isso Max Weber (2006) diz que Calvino, por meio de sua interpretação pragmática e materialista das escrituras, foi muito mais importante para a consolidação de uma religião moderna secularizada do que Lutero, já que sua visão de uma divindade vingativa e hostil, corroborada pela defesa da predestinação, levou milhares de indivíduos à insensatez do labor e do sacrifício como formas de remissão dos pecados.

A resposta imediata da Igreja católica foi censurar e reprimir os que defendiam e pregavam a Reforma, na expectativa de que as ideias de Lutero e Calvino não se expandissem e a unidade cristã fosse reestabelecida. Contudo, a esperança católica não se concretizou. Os abusos crescentes, o excesso de centralização do poder em Roma, as preocupações políticas e econômicas 
do clero - muito maiores do que as teológicas - acabaram tendo o efeito contrário, inflando a Reforma e aumentando ainda mais o fosso entre as Igrejas de Cristo.

\section{Conclusão: unindo pontos}

Para melhor se entender o significado da condição espiritual da Renascença, é preciso unir alguns pontos que talvez ainda não foram devidamente amarrados: a) o surgimento da crítica pagã tem que ser entendida de duas formas: ora como releitura da antiguidade e das próprias religiões pagãs, ora como renovação do próprio cristianismo; b) o resgate do antropocentrismo plantou as sementes de um pensamento religioso mais libertino e mundano, enquanto o letramento da população e uma nova atmosfera cultural ajudaram no desenvolvimento desta mentalidade religiosa inovadora, que, curiosamente, ainda não estava madura suficiente para revoltar-se contra a escravidão negra e o genocídio indígena nas Américas; c) a originalidade dos conflitos religiosos, durante o Renascimento, decorreu do surgimento de uma nova teologia e psicologia social, de cunho pagão, que se instalaram no seio da civilização ocidental, ajudando a mudar as perspectivas religiosas e culturais dos indivíduos modernos; tais mudanças foram essenciais para o desenvolvimento de outros aspectos da vida cotidiana como a atividade capitalista, a produção artística e literária e a virada epistemológica e científica.

Captando o "espírito" de seu tempo, Lutero legou ao ocidente uma teologia intimista e aberta, baseada no nominalismo, onde as críticas eram bem-vindas e os dogmas refutados. Obviamente, que sua intenção não era claramente esta, porém, como efeito de suas obras, lançou para dentro do indivíduo a fé, outrora intermediada pelas entidades exteriores da Igreja, suplantou os princípios imutáveis da religião em favor de normas mais desguarnecidas e intimou as autoridades seculares a interferirem nos assuntos de Deus. Com isso, assentou um duplo questionamento do catolicismo: um de cunho teológico e outro de cunho moral; e fez nascer uma nova forma de cristandade, baseada no ascetismo e na afirmação da voz popular. Enquanto a Igreja Católica insistia no controle moral de seus fiéis e pouco lhes ensinava sobre teologia, os reformadores restauraram a teologia da qual derivaria a moral. Os fiéis, assim, passaram a merecer mais atenção da(s) Igreja(s), ao passo que os clérigos perdiam áureas de santidade e os leigos ocupavam mais espaço no interior da cristandade. A Reforma, além disso, foçou a revisão 
das noções tradicionais de Igreja e sacerdócio num contexto em que o povo se erguia como júri e promotor da hierarquia e dos ministros de almas.

Se a filosofia cristã (escolástica) tinha um fundamento político e moral bem definido: Deus. Se Santo Agostinho e São Tomaz de Aquino, transformaram Deus no sumo legislador moral, naquele que cria e dita as regras morais da ação do homem. Se para eles as leis morais divinas existem a priori e a grande tarefa da cristandade é adequar à ética universal de Cristo as atividades particulares do cotidiano. Os humanistas do Renascimento resgataram as bases descristianizadas da filosofia clássica e trouxeram à tona, além de muitas outras coisas, a necessidade de um novo olhar sobre a vida moral e política, tornando, com isso, a secularização do debate éticopolítico a mola propulsora (a "herança maior") para que a vida pública (a ética da sociabilidade) passasse a ser pensada e responsabilizada a partir da ação individual: do indivíduo capaz de legislar acerca da melhor forma de viver e compartilhar a vida comum. Lutero deixou evidente a necessidade de estender ao campo religioso o anseio por autonomia e liberdade do período.

Por outro lado, o viés calvinista mostrou-se fundamental para estimular o experimentalismo como prática gnosiológica, principalmente porque: os calvinistas recusaram a hipótese de uma resolução estática da natureza que apenas poderia modificar-se por intervenção divina, ao passo que a respectiva autonomia religiosa e dos encargos, no protestantismo, incentivaram a ação própria e o empreendedorismo que se beneficiavam de um saber útil e pragmático, de ensaios que levassem a coisas práticas. A essa imagem ainda subjaz a noção, em uma sociedade em mudança, de que as descobertas úteis auxiliariam no equilíbrio e na paz social (Damião, 2018).

Em linhas gerais: o renascer da civilização ocidental foi um momento crucial de tomada de uma "nova consciência" ontológica do ser. Os intelectuais renascentistas, sobretudo no campo da estética e da literatura, reinventaram, ora com parcimônias, ora com distanciamentos, o antropocentrismo clássico. Os filósofos deste período, por sua vez, resgataram a razão como instrumento gnosiológico por excelência. A razão tornou-se o atributo necessário para iniciar e concluir quaisquer problemas epistemológicos. A retomada do antropocentrismo e da racionalidade, a seu turno, objetivaram-se através do naturalismo científico e da representação matemática do mundo. Já no campo espiritual, a nova epistemologia foi ao encontro do individualismo religioso do protestantismo e das suas ramificações, enquanto "fertilizou" o solo da racionalidade instrumental do 
(saber-fazer) capitalista. Não é por acaso, portanto, que Jean Delumeau (1984, p.119), afirmou que "o dinamismo do ocidente foi também o dinamismo de suas igrejas".

Referências:

ABBAgnAnO, N. Dicionário de Filosofia. Trad. Alfedo Bosi, 6. ed. São Paulo, WMF Martins Fontes, 2012.

ALMEIDA, M. O Triunfo da Escolástica, a Glória da Educação. Revista Educação e Sociedade, Campinas, Unicamp, Vol. 26, n.90, p. 17-39, 2005.

ANDERSON, P. As Origens da Pós-Modernidade. Trad. Artur Morão. Edições 70, Lisboa, 1998.

ARIÈS, P. História Social da Infância e da Família. Trad. D. Flaksman, Rio de Janeiro, LTC, 1979. (1)

ARENDT, H. A condição Humana. Trad. Roberto Raposo. Rev. Adriano Correia. 10. ed. Rio de Janeiro: Forense Universitária, 2007.

BAuman, Z. Em Busca da Política. Trad. Marcus Penchel. 1. ed. Rio de Janeiro, Zahar, 2000.

CALVINO, J. As Institutas. Vol III. Trad. Waldyr Carvalho Luz. São Paulo, Cultura Cristã, 2003.

DELUMEAU, J. A Civilização do Renascimento, Vol. 1. Trad. Manuel Ruas, Lisboa, Editora Estampa, 1994. 1984 .

A Civilização do Renascimento, Vol. 2. Trad. Manuel Ruas, Lisboa, Editora Estampa,

DAMIÃO, A.P. O Renascimento e as origens da ciência moderna: Interfaces históricas e epistemológicas. Revista História da Ciência e Ensino: Construindo Interfaces, Volume 17, p. 22-49, PUC, São Paulo, 2018.

ELIAS, N. O Processo Civilizador. Trad. Ruy Jungmann. Rio de Janeiro: Jorge Zahar Ed, 1994.

HALL, S. Quando foi o pós-colonial? Pensando no limite. In: Da diáspora: identidades e mediações culturais. Belo Horizonte: Editora UFMG. Brasília: Representação da UNESCO ao Brasil, 2003.

HENRY, J. A Revolução Cientifica e as Origens da Ciência Moderna. Trad. Maria Luiza X. de A. Borges. Rev. Henrique Lins de Barros. Rio de Janeiro, Jorge Zahar, 1998.

LUTERO, M. Obras Selecionadas. Vol II. O Programa da Reforma, Escritos de 1520. Trad. Martin Dreher; Ilson Kayser; Claudio Molz; Luís Sander e Walter Shulupp. São Leopoldo e Porto Alegre, Editora Sinodal e Concórdia Editora, 1987.

MONDIN, B. Curso de Filosofia: Os Filósofos do ocidente. Vol. II. Trad. Bênoni Lemos, $2^{a}$ ed. São Paulo, Edições Paulinas, 1986. 
SEYMOUR-SMITH, M. Os 100 livros que mais Influenciaram a Humanidade: A História do Pensamento dos Tempos Antigos à Atualidade. Trad. Fausto Wolff. 5. ed. Rio de Janeiro, Difel, 2002.

THOMPSOn, J. B. A Mídia e a Modernidade: Uma Teoria Social da Mídia. Trad. Wagner de Oliveira Brandão. 5. ed. Petrópolis, Vozes, 1998.

WEBER, M. A Ética Protestante e o Espírito do Capitalismo. Trad. Pietro Nassitti, São Paulo, Martin Claret, 2006.

Submetido em: 27-2-2019

Aceito em: 4-12-2019 